\title{
Strontium isotopic ratio in brines from the north-east of the Angara-Lenskiy artesian basin
}

\author{
Sergey Alexeev ${ }^{1}$, Ludmila Alexeeva ${ }^{1,2^{*}}$, Orfan Shouakar-Stash ${ }^{3,4,5}$ \\ ${ }^{1}$ Institute of the Earth's Crust, Russian Academy of Sciences, Siberian Branch, 664033 Irkutsk, \\ Russia \\ ${ }^{2}$ Irkutsk State University, 664003 Irkutsk, Russia \\ ${ }^{3}$ Isotope Tracer Technologies Inc, Waterloo, Ontario, N2V 1Z5, Canada \\ ${ }^{4}$ Department of Earth and Environmental Science, University of Waterloo, Waterloo, Ontario, N2L \\ $3 \mathrm{G} 1$, Canada \\ ${ }^{5}$ School of Engineering, University of Guelph, Guelph, ON, N1G 2W2, Canada
}

\begin{abstract}
The $\mathrm{Sr}$ isotopic composition was measured in a number of samples of highly concentrated oil-field brines from the Angara-Lenskiy artesian basin. The brines are contained in the salt-bearing and subsaltbearing hydrogeological formations at a depth of 1,500-3,000 m. They have high salinity (385-530 g/L) and high $\mathrm{Sr}$ content (2.3-7.0 mg/L). The ${ }^{87} \mathrm{Sr} /{ }^{86} \mathrm{Sr}$ ratio ranges from 0.70800 to 0.713062 . Most brine samples exhibit an isotopic composition similar to Vendian-Cambrian paleoocean water, however several samples from the Yaraktinskiy horizon are significantly more radiogenic than others. It suggests that a considerable amount of ${ }^{87} \mathrm{Sr}$ is likely to have been carried from terrigenous sediments due to a water-rock interaction.
\end{abstract}

\section{Introduction}

The Angara-Lenskiy artesian basin (AB) is situated in the south of the Siberian Platform (Fig. 1). In its north-eastern part, a number of oil-gas fields were discovered, with

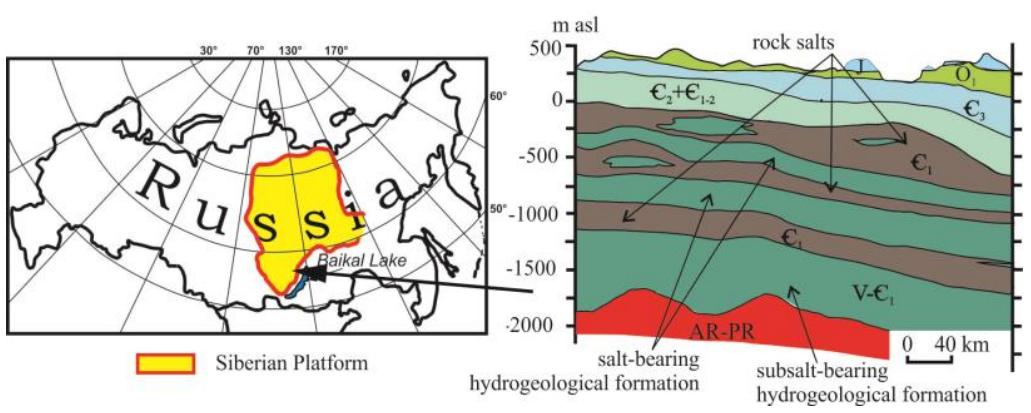

Fig. 1. Typical geological section of the Angara-Lenskiy AB.

\footnotetext{
*Corresponding author: lalex@ crust.irk.ru
} 
producing horizons connected to Vendian-Cambrian carbonaceous-terrigenous deposits. To increase hydrocarbon production, a clear picture of the hydrogeological setting, the groundwater flow and the groundwater chemical composition is needed. Even though strontium is one of the main dissolved ions in oil-field brines, the ${ }^{87} \mathrm{Sr} /{ }^{86} \mathrm{Sr}$ radiogenic isotopic ratio is still poorly studied. The strontium isotopic composition of brines is helpful to identify dissolved strontium sources which, in turn, provides information about the origin and evolution of the aquifer systems in oil-prone basins.

\section{Geological and hydrogeological setting}

A crystalline Archean-Proterozoic basement occurs almost everywhere at a depth of 2,000$4,000 \mathrm{~m}$. The lower part of the sedimentary cover is represented by carbonaceousterrigenous rocks $\left(\mathrm{V}-\mathrm{C}_{1}\right)$ - subsalt-bearing hydrogeological formation. The brine-bearing complex is $360-380 \mathrm{~m}$ thick. The aquifers within the terrigenous part of the formation are hydraulically connected. Brines within the carbonate part of the formation are $\mathrm{Na}-\mathrm{Ca}$ (rarely $\mathrm{Mg}-\mathrm{Ca}$ ) $\mathrm{Cl}$ with salinity varying from 240 to $530 \mathrm{~g} / \mathrm{L}$.

Just above the subsalt-bearing formation, in the halogenous rocks (halite, silvite, gypsum, anhydrite etc.), lies a salt-bearing hydrogeological formation $\left(\epsilon_{1}\right)$. The thickness of the rock salt beds varies from several meters to $100 \mathrm{~m}$. The rock salt strata are interbedding with strata of carbonaceous rocks - dolomites and limestones. The brine chemical composition is $\mathrm{Ca}-\mathrm{Cl}$ with a high content of $\mathrm{K}, \mathrm{Br}$ and trace elements. Brine salinity is 400-630 $\mathrm{g} / \mathrm{L}$, reaching the highest concentration found in all the Siberian Platform.

\section{Analytical methods}

The strontium isotopic ratio was measured using a multiple-collector mass-spectrometer MI-1201AT through the double Re-Re tapes technique at the Center of Multiple Element and Isotopic Research, Siberian Branch, Russian Academy of Sciences (Novosibirsk). Rb and $\mathrm{Sr}$ were extracted by ion chromatography on quartz columns filled with Dowex AG W50x8 resin, eluent being $2 \mathrm{~N} \mathrm{HCl}$. The correctness of ${ }^{87} \mathrm{Sr} /{ }^{86} \mathrm{Sr}$ ratio was ensured by parallel measurements of each series of water samples according to the VNIIM isotope standard with ${ }^{87} \mathrm{Sr} /{ }^{86} \mathrm{Sr}=0.70800 \pm 7,2 \sigma, \mathrm{n}=6$, and SRM 987 with ${ }^{87} \mathrm{Sr} /{ }^{86} \mathrm{Sr}=0.71026 \pm 6,2 \sigma$, $\mathrm{n}=6$.

Strontium isotopic analyses were also carried out at Isotope Tracer Technologies Inc. (Waterloo, Canada). The analysis was carried out on a Thermal Ionization Mass Spectrometry (TIMS), TI-Box (Spectromat, Bremen, Germany) by the single degassed rhenium filament method. Filament holders with degassed and oxidized filaments are mounted on the loading device and placed inside a positive laminar flow air-chamber. The sample is loaded onto the filament using a micropipette. The samples are dried and mounted onto the Triton analysis magazine with filament shields. Calibrated internal standards are run at the beginning and end of every run, as well as after every 8-10 samples. These standards have been calibrated to NIST SRM 987.

\section{Results}

The ${ }^{87} \mathrm{Sr} /{ }^{86} \mathrm{Sr}$ ratio was measured for 16 brine samples from the $\mathrm{V}-\mathrm{C}_{1}$ salt-bearing (Bulaiskaya and Usol'skaya suits) and subsalt-bearing (Nepskaya, Motskaya and Teterskaya suits) hydrogeological formations of the Angara-Lenskiy AB. The brine chemical composition is $\mathrm{Cl}-\mathrm{Ca}, \mathrm{pH}=4-5.35$, with salinity of $385-530 \mathrm{~g} / \mathrm{L}$ and $\mathrm{Sr}$ content of 
2,353-7,052 mg/L. One water sample with Cl-Na composition and $95 \mathrm{~g} / \mathrm{L}$ salinity was used for comparison (see Table 1).

Table 1. $\mathrm{Sr}$ and ${ }^{87} \mathrm{Sr} r{ }^{86} \mathrm{Sr}$ content in brines.

\begin{tabular}{|c|c|c|c|c|c|c|}
\hline $\begin{array}{c}\text { №, } \\
\text { borehole }\end{array}$ & Location & $\begin{array}{l}\text { Sampling } \\
\text { depth, } m\end{array}$ & $\begin{array}{c}\text { TDS, } \\
\text { g/L }\end{array}$ & $\begin{array}{l}\mathrm{Ca}^{2+}, \\
\mathrm{mg} / \mathrm{L}\end{array}$ & $\begin{array}{l}\mathrm{Sr}^{2+}, \\
\mathrm{mg} / \mathrm{L}\end{array}$ & ${ }^{87} \mathrm{Sr} /{ }^{86} \mathrm{Sr}$ \\
\hline $\begin{array}{c}1, \\
\text { brh.3 }\end{array}$ & \multirow{6}{*}{$\begin{array}{l}\text { Usol'skaya suite, } \\
\text { Osinskiy horizon }\end{array}$} & $2,926-3,074$ & 514.7 & 145.0 & 7,052 & 0.70814 \\
\hline 2, brh. 323 & & $2,992-3,052$ & 499.5 & 143.3 & 6,706 & 0.70824 \\
\hline $\begin{array}{c}3, \\
\text { brh.32 }\end{array}$ & & $2,599-2,640$ & 444.5 & 121.2 & 5,174 & 0.70821 \\
\hline 4, brh. 323 & & $2,992-3,052$ & 529.6 & 156.9 & 6,795 & 0.70800 \\
\hline $\begin{array}{c}13, \\
\text { brh.1 }\end{array}$ & & 2,381 & 509.1 & 145.0 & 6,514 & 0.70826 \\
\hline $\begin{array}{c}15, \\
\text { brh.1 }\end{array}$ & & $1,559-1,586$ & 95.7 & 7.1 & 112 & 0.70845 \\
\hline $\begin{array}{c}14, \\
\text { brh. } 72\end{array}$ & $\begin{array}{c}\text { Bulaiskaya suite, } \\
\text { Berkinskiy horizon }\end{array}$ & 1,670 & 426.3 & 98.7 & 3,452 & 0.70872 \\
\hline 6, brh.028 & \multirow{2}{*}{$\begin{array}{l}\text { Motskaya suite, } \\
\text { Parfenovskiy horizon }\end{array}$} & $2,520-2,530$ & 504.6 & 140.5 & 3,246 & 0.70846 \\
\hline 7, brh.028 & & $2,520-2,538$ & 497.0 & 133.5 & 4,588 & 0.70835 \\
\hline $\begin{array}{c}5, \\
\text { brh.97 }\end{array}$ & \multirow{4}{*}{$\begin{array}{l}\text { Nepskaya suite, } \\
\text { Yaractinskiy horizon }\end{array}$} & $2,973-2,986$ & 384.9 & 92.0 & 3,523 & 0.71252 \\
\hline 8, brh. 175 & & $3,293-3,590$ & 390.6 & 94.1 & 3,508 & 0.71264 \\
\hline 9, brh.157 & & $3,085-3,094$ & 394.5 & 98.7 & 3,788 & 0.71306 \\
\hline 10, brh. 247 & & $3,319-3,360$ & 389.9 & 94.0 & 3,817 & 0.71253 \\
\hline $\begin{array}{l}11, \\
\text { brh. } 1\end{array}$ & $\begin{array}{c}\text { Teterskaya suite, } \\
\text { Nizhneust'kutskiy } \\
\text { horizon }\end{array}$ & $1,956-1,965$ & 409.3 & 82.8 & 2,565 & 0.70863 \\
\hline $\begin{array}{l}12 \\
\text { brh.11 }\end{array}$ & $\begin{array}{c}\text { Katangskaya suite, } \\
\text { Preobrazensky } \\
\text { horizon }\end{array}$ & $1,754-1,771$ & 401.1 & 91.7 & 2,353 & 0.70862 \\
\hline $\begin{array}{c}16, \\
\text { brh. } 2231\end{array}$ & $\begin{array}{l}\text { Nepskaya suite, } \\
\text { Verkhnechonskiy } \\
\text { horizon }\end{array}$ & 1,650 & 398.3 & 104.9 & 2,519 & 0.71012 \\
\hline
\end{tabular}

Note: brines from salt-bearing hydrogeological formation are in grey.

The ${ }^{87} \mathrm{Sr} /{ }^{86} \mathrm{Sr}$ ratio in brines of the salt-bearing hydrogeological formation varies within a narrow range of $0.70800-0.70872$, while is wider in the subsalt-bearing formation (0.708350-0.713062) (Fig. 2). The histogram and diagrams also display strontium isotope ratios in $\mathrm{Cl}-\mathrm{Ca}$ brines occurring in carbonate sediments and kimberlite rocks of the Olenekskiy $\mathrm{AB}$, Western Yakutia [1] for comparison with brines in non-salt-bearing formation.

The ${ }^{87} \mathrm{Sr} /{ }^{86} \mathrm{Sr}$ values in ground waters vary according to the radiogenic strontium content, which is a ${ }^{87} \mathrm{Rb}$ radioactive decay product in primary sources - rocks and paleoocean waters. Apart from that, the strontium isotope ratio varies with lithological composition of host rocks, that is on the origin and formation stage of schists and sandstones in terrigenous rocks and on the age and degree of change of marine carbonates, evaporates and phosphorites in carbonate rocks [2].

Highly concentrated $\mathrm{Ca}-\mathrm{Cl}$ brines of salt-bearing and subsalt-bearing formations of the Angara-Lenskiy $\mathrm{AB}$ are confined to terrigenous and carbonate sediments deposited at a depth of 1,500-3,000 $\mathrm{m}$. The brines are found in the hydrodynamic passive water exchange zone. Their chemical composition is a result of geochemical metamorphisation of connate 
water in the salt basin at Vend/Cambrian boundary and further interaction with terrigenous rocks and carbonates.

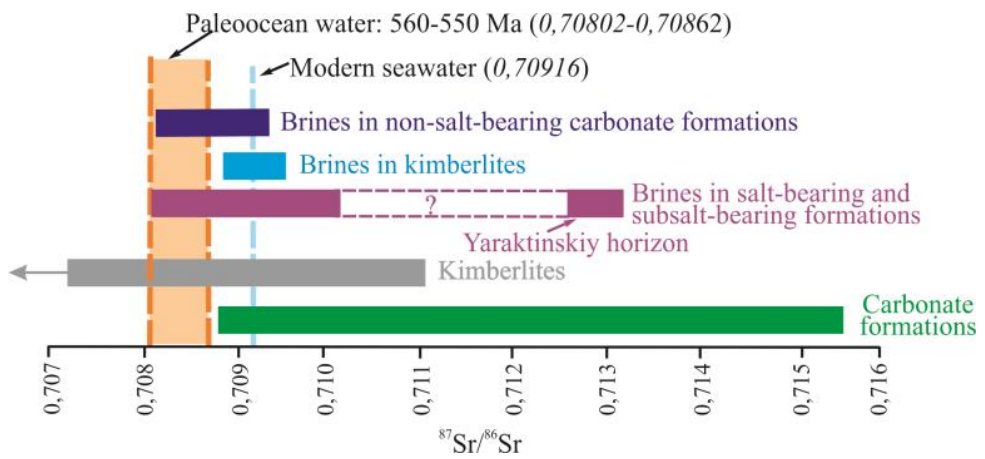

Fig. 2. Sr isotope ratio measured in brines from different geological environments: paleoocean water [3, 4]; modern seawater [2]; brines in non-salt-bearing carbonate formation (Olenekskiy AB, depth of $115-1,650 \mathrm{~m}$ ); brines in kimberlites (Olenekskiy AB, depth of 170-630 m); brines in salt-bearing and subsalt-bearing formation (Angara-Lenskiy AB, depth of 1,500-3,500 m; question mark - no data); in rocks: kimberlites ([5], depth of 50-800 m); carbonate formation (Olenekskiy AB, depth of 265$1,500 \mathrm{~m})$.

Initial isotopic strontium ratios in paleoocean water in the Vendian-Cambrian period $(575-550 \mathrm{Ma})$ varied between 0.70802 and $0.70862[3,4]$. Almost all strontium ratio values measured in samples of highly concentrated brines from salt-bearing and subsalt-bearing hydrogeological formations fall within the range typical of modern seawater and paleoocean water (Fig. 3).

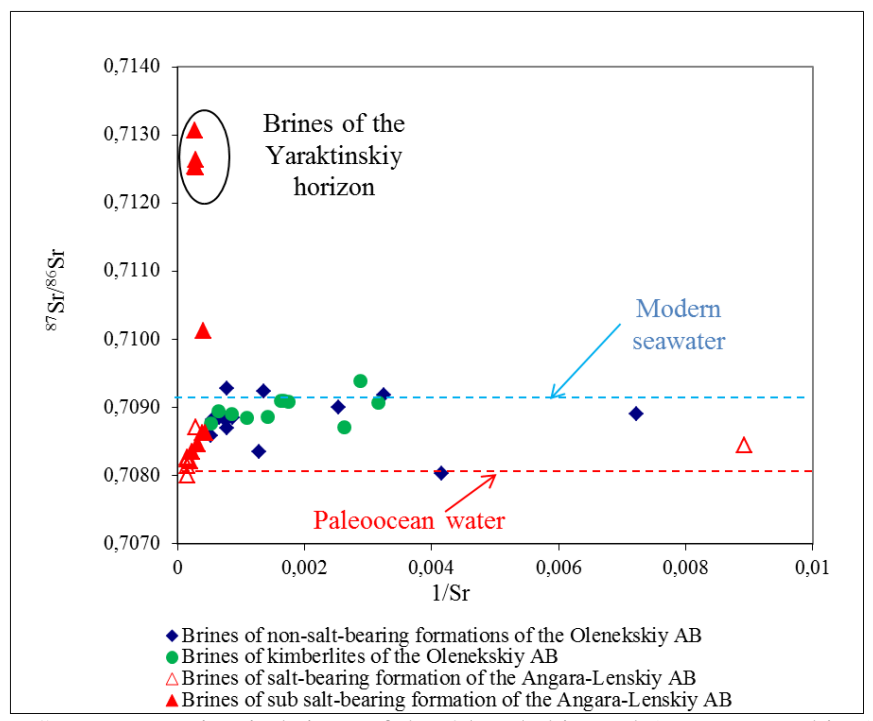

Fig. 3. ${ }^{87} \mathrm{Sr} /{ }^{86} \mathrm{Sr} v s \mathrm{Sr}$ concentration in brines of the Olenekskiy and Angara-Lenskiy AB.

An exception are the brines from the Yaraktinskiy horizon, Nepskaya suite (subsaltbearing hydrogeological formation), which are displayed in the charts in a special group distinguished by a higher ${ }^{87} \mathrm{Sr} /{ }^{86} \mathrm{Sr}$ ratio $(0.71252-0.71306), \mathrm{Sr}^{2+}$ content being 3.5-3.8 g/L. They far exceed ${ }^{87} \mathrm{Sr} /{ }^{86} \mathrm{Sr}$ ratio typical of modern sea water and paleoocean water at the boundary of the Vendian and Cambrian. What is the reason for the high radiogenic strontium content in highly concentrated brines and what is its source? 
The Yaraktinskiy oil-gas horizon coincides with the Nepskaya suite at the base of the sedimentary cover at a depth of 2,600-2,700 m. Essentially the sandy sediments of the Yaraktinskiy horizon accumulated during the late Vendian Nepsky period (575-585 Ma) in shallow shelf conditions where the coastal plain was occasionally flooded by the sea [6]. The major source of clastics was the internal regions of the Siberian Platform, as well as local protrusions of the heterogeneous crystalline basement. Temporary streams transferred a large amount of rock disintegration products, probably enriched in rubidium that in the first place filled erosive landforms and adjacent areas with sandy-siltstone material. This increased the radiogenic strontium content and ${ }^{87} \mathrm{Sr} /{ }^{86} \mathrm{Sr}$ isotopic strontium ratio. During sea transgression the marine sedimentation environment formed a clayey bed made of argillites from greenish-grey to black, lightly micaceous, pyritized and probably with an elevated strontium isotopic ratio. A further transformation of sandstones, argillites and siltstones of the Yaraktinskiy horizon and ground water interaction with rocks enriched in radiogenic strontium led to ${ }^{87} \mathrm{Sr}$ dissolution. In order to give an accurate answer to the question about the source of radiogenic strontium, it is necessary to determine the isotopic strontium ratio in terrigenous sediments of Yaraktinskiy horizon. This is a priority of our future research.

\section{Conclusions}

${ }^{87} \mathrm{Sr} /{ }^{86} \mathrm{Sr}$ values in chloride calcium brines of salt-bearing and subsalt-bearing hydrological formations of the Angara-Lenskiy AB correspond mainly with the Sr ratio in water of the Cambrian paleoocean. An exception is the Yaraktinskiy horizon brines, which are quite enriched in radiogenic strontium, a possible reason being the terrigenous sediments settled out due to a water-rock interaction.

The study has conducted with the financial support of the Russian Science Foundation (№ 17-1701158). The authors are grateful to A.G. Vakhromeev and E.O. Chertovskikh for the brine samples provided. The manuscript was improved by constructive comments from anonymous reviewers.

\section{References}

1. L.P. Alexeeva, S.V. Alexeev, Geol. and Geoph. 59, 2 (2018)

2. J.L. Banner, E-Sc. Rew. 65 (2004)

3. J.M. McArthur, R.J. Howarth, G.A. Shields, The geologic time scale 2012 (Chapter 7, 2012)

4. I.A. Vishnevskaya, B.B. Kochnev, E.F. Letnikova et. al., DAS 449, 3 (2013)

5. M.N. Maslovskaya, $\mathrm{PhD}$ thesis (1985)

6. N.V. Mel'nikov, Vend-Cambrian salt-bearing basin of the Siberian Platform (2018) 